\title{
Insistent emplacement: Heidegger on the technologies of informing
}

\author{
Steven D. Brown and Geoffrey M. Lightfoot \\ Centre for Social T heory \& Technology, Department of Management, \\ Keele University, Staffordshire, UK \\ In Dasein there lies an essential tendency towards closeness. A II the ways in which we speed \\ things up, as we are more or less compelled to do today, push us on towards the conquest of \\ remoteness (Heidegger, 1962, p. 140).
}

\section{I}

To get us under way, consider a now familiar image: the manager who has his/her secretary print out his/her e-mails and stack them high for subsequent perusal. Not quite apocryphal enough, this practice - the source of many cartoons and much "back stage" grumbling - expresses a not-so-subtle judgement about information technology. We suppose that it breaks roughly into two distinct elements. The first is a suspicion about the quality of what is communicated. Much of it is thought to be trivial, narrow in its content or simply superfluous and counter-productive to ordinary thinking: in short, inessential. It takes time, after all, to say anything worthwhile, and by its very nature information technology inverts our sense of the temporal. The second is what might be called a mis-attunement to technology. The medium itself feels wrong, strangely inauthentic, perhaps because it seems to require so little effort. It is not the means by which great oratory is heard, certainly, but more than this there is a sense of risking disruption, of falling foul of poor mediation, that makes information technology seem a weak substitute for the handwritten word or conversation. A nd one can almost audibly hear these beliefs hardening in response to the recent spectacle of the Hollywood movie star who faced down poor reviews with the claim that, in his milieu, the Internet, and not professional film critics, was the prime source for instant, accurate information.

Instantaneity corrupts or distracts, then? Or simply speeds without direction? We are up against a well-worn diagnosis for modern times, one whose origins are entirely coeval with the passage to modernity itself. As Thoreau has it during the mid-nineteenth century: work is partly supported by a grant from the ESRC (L132251042) as part of the Virtual Society? 
Why should we live with such hurry and waste of life? We are determined to be starved before we are hungry. Men say that a stitch in time saves nine, so they take a thousand stitches today to save nine tomorrow (T horeau, 1854, cited in K aleb, 1997, pp. 1238-9).

Here technology serves no other need than its own rapacious impulse to achieve more in less time. But this "more" is directed towards no fitting end, it becomes a goal or a limit point to be constantly exceeded. Life is "wasted" in the obsession with haste. Such pronouncements are followed in due course by the critical observers of postmodernity with their analyses of how the compression of time and space by technology leads relentlessly to new systems for the disassembling and control of social space (Haraway, 1991; Harvey, 1989). This draws out a further issue: in its conquest of speed, modern technology, as the telecommunications providers are apt to put it, brings us closer to one another, but in doing so it effaces not only distance, but also the sense of duration. The passage of lived time with all its pauses, swollen by memory and anticipation, is exchanged for the business of managing connection time. The sense of place, grounded in our relation to a particular space, becomes overwritten with the possibility of getting on-line with A merica.

This massive proximity, granted by the power of technology, characterises our contemporary understandings of informing. To gain some purchase on why such proximity can become so discomforting, we might simply ask what it is that we are informed about by modern technologies of informing? The immediate reply is the world, in the most general sense of everyday events and occurrences, and in the course of this unstoppable flow of information, something about ourselves. In Sherry Turkle's (1984) remarkably prescient The Second Self, there is already a complete outline of what is now almost a truism: technology is good to think with. It provides a mirror in which we discern images of what we are, in ourselves. That is, the way of being that our personal being takes. Thus Turkle's informants grapple with weighty questions about the nature of life, death, society and selfhood all in the course of coming to grips with (now much outmoded) electronic artefacts. Yet in this there is a premonition, perhaps exemplified by the unforgettable image of Marvin Minsky starry eyed with the metaphors provided by Disney's Tron, that the ways of being we glimpse while caught by the "holding power" of technology can rapidly reveal themselves as insubstantial banalities, thin and vastly impoverished versions of existence: inauthentic, inessential. Perhaps this is why our nameless manager chooses not to look too closely into the screen.

\section{II}

A nd so to Heidegger. The question of existence, the "is" which defines being, dominates Heidegger's work, from Being and Time to the later reflections on language, poetry, science and philosophy. Being must be understood here as a verb, as expressing how things proceed forth in their existence. The manner of being which such questioning continually approaches is not that which defines this or that particular being (entity), but rather the "being of beings", the is-ness which properly belongs to all beings. This is what differentiates the "being 
question" (Seinsfrage) as it historically unfolds in the care of philosophy from the particular "calculative" questions about the nature of the world which are posed by science.

But the very basis of this division between the being question and science itself bears testimony to the importance of the human as Dasein ("being here"), or that being for whom its own being is a fundamental concern. Dasein, the human, has available to it as modes of its own being both the possibility of enquiring into the qualities of other beings (concerning their "whatness") and that of turning to question its own ontological constitution. This latter mode of being proper to Dasein Heidegger calls Existenz. Existenz (usually somewhat narrowly translated as existence) is one of the many "ontical affairs" of Dasein. By this Heidegger means that fundamental enquiry into existential matters is itself approached by way of the kinds of everyday quotidian concerns and questioning which characterise much of lived experience. The understanding garnered by this more mundane questioning he calls existentiell:

Dasein always understands itself in terms of its existence - in terms of a possibility of itself: to be itself or not itself. Dasein has either chosen these possibilities itself, or got itself into them, or grown up in them already. Only the particular Dasein decides its existence, whether it does so by taking hold or by neglecting. The question of existence never gets straightened out except through existing itself. The understanding of oneself which leads along this way we call "existentiell" (Heidegger, 1962, p. 33).

In choosing to question our own being, which is itself the pathway toward the wider question of being, we are realising a fundamental mode of that being, thus existence never gets straightened out except through existing itself. Of course we may choose not to do so, or may simply neglect the question at all, in which case we fail to get under way in approaching the being question. We remain in the existentiell, without passing to existenz. In other words, what is described here is the appearance of a choice: to be oneself by questioning oneself, or to be not oneself by pursuing other "ontical affairs", a turning away from being.

Let us take some bearings from this all too hasty rendering of early Heidegger. Perhaps the simplest way to read it is to note that it appears to be driven by questions of what is authentic and what is essential. Existenz - that mode of being wherein we begin to apprehend our own being - might on this reading correspond to living in authenticity, whereas the existentiell life is fundamentally inauthentic. Likewise, the distinction between the ontical, as those questions which deal with appearances and thus fail to achieve purchase on the essential nature of things, and the ontological, as an account of essence of beings in their actuality, seems to reinforce the impression of a basic division between the trivial and the essential. And let us add to this the further distinction between questioning oneself and questioning the world to produce two sets of associations: inauthentic, inessential, outer-directed versus authentic, essential, inner-directed.

Have we not now come full circle to that prejudice with which we began? Perhaps, if we now just add the following terms to each list: information (inauthentic, inessential, outer-directed) and knowledge (authentic, essential, 
inner-directed). On this account, information is that mode of understanding in which the "ontical business" of Dasein is conducted. It is what is sought by all calculative questioning, which is itself grounded in the manipulation and bringing into immediate use of beings. This Heidegger refers to as readiness-athand. That which is "to hand" is both available for immediate use and "close" to us in the cognitive sense. Its usefulness takes on a "character of inconspicuous familiarity":

Every entity that is "to hand" has a different closeness, which is not to be ascertained by measuring distances. This closeness regulates itself in terms of circumspectively "calculative" manipulating and using. A the same time what is close in this way gets established by the circumspection of concern, with regard to the direction in which the equipment is accessible at any time. When this closeness of equipment has been given directionality, this signifies not merely that the equipment has its position [Stelle] in space as present-at-hand somewhere, but also that as equipment it has been essentially fitted up and installed, set up and put to rights (Heidegger, 1962, p. 135).

We take for granted our ability to use what is "to hand" for calculative questioning, that is informing, because it is directly available to us. Yet this availability must first be established by the "installing" or "setting up" of the ready-to-hand; here not just in the sense that any equipment must be properly configured and functioning efficiently, but also that we must be convinced of the adequacy of the representational set-up in which the equipment is fixed. The information it provides must appear at least to be informing us about matters at hand. We must be convinced that there is a necessary connection between the order that emerges in the answers to our calculative questioning and the order that we presume to exist amongst beings. It is when this connection comes under strain, for whatever reason, that we are likely to recognise our failure to "find something in its place" (Heidegger, 1962, p. 138).

The displacing of whatever is "to hand" forces us to consider anew the "region" in which that equipment was set up. Calculative questioning is then replaced by a more thoroughgoing scrutiny. It is this kind of enquiry that we might see as resulting in knowledge proper. In other words, as long as our technologies of informing are functioning adequately, we may choose to entirely ignore the manner in which they actually set about informing us. Yet, when a problem arises which calls into question this mode of informing, then we are impelled to reflect upon the very nature of the technology which serves us and its relation to the world.

This failure to inform which spurs reflection on that which grounds the technology itself is the general circumstance that Winograd and Flores (1986) call "breakdowns". Breakdowns impel questioning towards knowledge, just as the "inconspicuous familiarity" of the "to hand" serves the incessant desire for information. To complete our account we have only to add that these two modes of understanding, the one aimed at what is essential, the other at what is readyto-hand and thus tending toward the superficial, have very different temporal characteristics. K nowledge occurs in the wake of the breakdown. It proceeds slowly, perhaps without clear direction. Information is governed entirely by its 
ITP

11,4

294 readiness, its immediacy. It is set completely in place by the technologies which make it possible.

\section{III}

A t first glance, the use we have made of Heidegger so far simply confirms the rhetorical commonplace of information as a degraded form of knowledge. Every commonplace of this kind contains within it an opposing argument (see Billig, 1996), such that each position comes to define itself against the other. We hazard that the counterpoint here comes from those zealots of the Internet - an unlikely grouping that ranges from Bill Gates to anarchic hackers. Their belief that limitless information, available to all, shared by all, will allow unbounded utopian possibilities runs the discourse of authenticity the other way round. Here, one can gain existential understanding through accessing the truth that is out there, downloading the vital pages and, through gathering sufficient information, making the necessary connections that will ultimately explain everything, everywhere. This celebratory rhetoric now aligns the discourse of authenticity with the accretion of information.

Perhaps the ease with which "authenticity" can be turned now this way and then that gives pause for thought. In each case, the authentic seems to be whatever mode of being is deemed most likely to lead to an appreciation of what is essential. For Heidegger, this inevitably returns to the fundamental ontology at whose heart is the being of all beings. For our Internet aficionados, this means an involvement in the utopics of cyberspace. Yet however much this hastily arranged opposition may appear to hold - Heidegger being, after all, that philosopher whose critiques of modern science and technology have been most often associated with a conservative vision of modernity (see Steiner, 1992; Zimmerman, 1990) - it relies on keeping the division of authenticity and the essential from inauthenticity and the inessential firmly in place. The immediate problem, however, is of deciding how to apportion authenticity when it may be equally well claimed by either side. We lack an adequate model against which to judge. A nd if there is no model of authenticity, we are also left with a similar confusion in how to denote what is properly essential. Thus do we find ourselves in a classic Heideggerian quandary: a failure to adequately grasp those terms and ideas which appear to be most close to us.

We may yet take direction, though, by following Heidegger's discussion of truth, which closely relates to our present difficulty with authenticity. Heidegger's essay "On the essence of truth" begins by attempting to describe the "usual conception" of truth. This is found in the notion of the actual. That which is true conforms in its "actuality" to our prior expectations. Thus a piece of metal may be confirmed as "actual gold" when on inspection it conforms to our al ready established ideas of what constitutes gold. Truth is then a matter of accordance:

Genuine gold is that actual gold the actuality of which is in accordance with what, always and in advance, we "properly" mean by "gold". Conversely, wherever we suspect false gold, we say: "Here something is not in accord". On the other hand, we say of whatever is "as it should be": "It is in accord". The matter is in accord (Heidegger, 1993a, p. 117). 
That which appears to us to be "as it should" is in accord, hence true. Conversely statements about matters may themselves be true when they accord with the matter itself. This is again underpinned by what "always and in advance" we properly understand to constitute the proper "whatness" of the matter in hand. On these grounds, we may also say that the "truth" of authenticity is also a matter of accordance with previously established expectations. Yet this clearly raises an issue of what we can now expect from "truth" itself, since it is thereby made subservient to the determination of our prior understandings. For Heidegger this development in the "usual meaning" of truth can be traced to the replacement of God as the author and transcendental guarantor of divine creation with the dominance of reason as that which grasps worldly order:

The theologically conceived order of reason is replaced by the capacity of all objects to be planned by means of worldly reason which supplies the law for itself and thus also claims that its procedure is immediately intelligible (what is considered "logical"). T hat the essence of propositional truth consists in the correctness of statements needs no further special proof. Even where an effort is made - with a conspicuous lack of success - to explain how correctness is to occur, it is already presupposed as being the essence of truth (Heidegger, 1993a, p. 119).

Reason supplies its own guarantee. This is the historic difficulty always confronted by the correspondence theory of truth: that one has to eventually simply accept that reason, when properly applied, is endowed with a miraculous capacity for "correctness". Truth becomes a matter that is settled entirely by the rhetorical power of reason, which has itself historically been used to warrant all kind of social injustice (see Brown et al., 1998; T soukas, 1992).

Heidegger's way forward is to explore the various senses in which correctness (that is, accordance) may occur. All imply a fundamental relationship between an act of presenting and the presentation of some thing itself. Presentative acts, such as statements or propositions, must "let the thing stand opposed as object" (Heidegger, 1993a, p. 121). They allow matters to stand as they are in themselves. In order to do this presentative acts must take an "open stance", meaning they must allow themselves to be directed towards what is "opened up" in the thing which stands. This Heidegger calls comportment:

Comportment stands open to beings ... All working and achieving, all action and calculation, keep within an open region within which beings, with regard to what they are and how they are, can properly take their stand and become capable of being said. This can occur only if beings present themselves along with the presentative statement so that the latter subordinates itself to the directive that it speaks of beings such-as they are. In following such a directive the statement conforms to beings. Speech that directs itself accordingly is correct (true) (Heidegger, 1993a, p. 122).

Presentative acts which adopt proper comportment are necessarily correct because they allow themselves to be directed to what is opened up in beings. Thus are they true. Note also that Heidegger does not here make a distinction in 
this regard between calculation - what we have discussed as informing - and may conclude that so long as informing adopts proper comportment, it is also necessarily correct and so "true". This point is decisive for our present discussion, since is suggests that there is nothing in the essence of informing which defines it as such as degraded knowledge. Informing shares the potential for correctness that is held by all forms of understanding.

Does this then mean that once the proper comportment has been adopted, technologies of informing may aspire tow ards a "utopia of communication" that is, moreover, "correct" and "true" in its working and achieving? Not without eliding a subtle twist in Heidegger's account. Comportment "lets being be" by addressing itself to what is opened up within them. The very notion of this "opening up" implies a movement from closure. This latter Heidegger names concealment. Concealment is prior to all openness. It is the "mystery" wherein the full plenitude of being is withheld. A s such, it is also the only proper grounds upon which "truth", as proper comportment towards the opening up of unconcealment can be founded. Since concealment is by definition opposed to truth, Heidegger characterises it as "un-truth". He thereby realises an almost paradoxical description of truth as nourished and sustained by its relation to what is un-true:

The concealment of beings as a whole, untruth proper, is older than every openedness of this or that being. It is also older than letting-be itself, which in disclosing already holds concealed and comports itself toward concealing. What conserves letting-be in this relatedness to concealing? Nothing less than the concealing of what is concealed as a whole, of beings as such, i.e. the mystery (Heidegger, 1993a, p. 130).

Letting-be can never dispense with this relation to concealment, since it can never exhaust the plenitude of being in its capacity to come out tow ard unconcealment in manifold ways. Or to put it in a more banal fashion, no matter how exhaustive our modes of enquiring, something always withdraws from knowledge. The world (or to use Heideggarian terminology, the earth) is never entirely used up in coming to our knowledge. Yet even though we may not ever fully expose concealment, we may perhaps in some way choose to ignore or simply forget the potency of concealment's mystery. This occurs because of our irresistible attraction towards what is opened up, which leads us to turn away from the concealed. That which attracts us most is what is al ready to hand and immediate:

$[T$ ]his bearing toward concealing conceals itself in the process, letting a forgottenness of the mystery take precedence and disappearing in it. Certainly man [sic] takes his bearings constantly in his comportment toward beings; but for the most part he acquiesces in this or that being and its particular openedness. $M$ an clings to what is readily available and controllable, even where ultimate matters are concerned. A nd if he sets out to extend, change, newly assimilate, or secure the openedness of the beings pertaining to the most various domains of his activity and interest, then he still takes his directives from the sphere of readily available intentions and needs (Heidegger, 1993a, p. 130).

As our activities become structured by needs and intentions that are themselves functions of the mere availability of the ready-at-hand (the "need", 
for example, to be constantly accessible to others which has its roots in the technology of mobile telecommunications), so does our forgetfulness of being and the mystery of concealment increase. Here "availability" finds its apotheosis in the pursuit of speed and the quest for ever greater closeness, which become in turn values to supersede all others. So while there is nothing in the essence of informing and calculative questioning which leads to this forgetting, as soon as informing impels us to value availability above all else, then it begins to exert a fateful holding power:

By disavowing itself in and for forgottenness, the mystery leaves historical man in the sphere of what is available to him, leaves him to his own resources. Thus left, humanity replenishes its "world" on the basis of the latest needs and aims, and fills out the world by means of proposing and planning. From these man takes his standards, forgetting being as a whole. He persists in them and continually supplies himself with new standards, yet without considering either the ground for taking up standards or the essence of what gives the standard (Heidegger, 1993a, p. 132).

A fateful situation indeed, and one that is far more perilous than the supposed meltdown of all truth brought about by postmodern relativism. Heidegger names this modern way of being "insistence" or a holding fast to what is offered by beings as though they were open of and in themselves. By this we may understand both that modern informing demands or "insists" on the value of availability and that the life or "insistence" (as opposed to exsistence) that we are thereby led towards is one which is completely detached from any relationship to fundamental being.

\section{IV}

A brief return to our harassed manager. The door closes, leaving him alone with the latest bundle of printed e-mails to be read. His eyes hover briefly on the top paper, then the next, trying quickly to ascertain the identity of the senders amongst the jumble of codes and protocols. The effort is too great. Soon the manager's attention wanders back to the other documents and memoranda which occupy his desk. They in turn are briefly scrutinised, pen held hovering over each one. Gradually time is eked away until the next round of appointments and meetings are due.

W hat we have thus far ascertained about modern informing from our discussion of Heidegger can obviously be generalised beyond the case of information technology. There are a great many media by means of which we are informed, all of them pressing for our attention. A nd by merely choosing to use information technology in a different way, by insisting on hard copy, our manager is able to strip away any special claims to immediacy and proximity present in any one medium, thereby reducing the flows of informing appearing on their desk into a standardised array. Where then are we to find the essence of the particular availability of information technology, as against all the other media of informing? Perhaps by considering what is meant in this instance by "technology". 

T ime (see Dreyfus, 1992). In his early writings technology is still considered as a species of equipment. This latter marks any ready-at-hand being which stands available for some use by humans. A hammer, for example, is a rudimentary piece of equipment much discussed by Heidegger. Beings that show themselves as equipment do so in the context of a certain set of relations to other beings. The spatiality of these relations is referred to in Being and T ime as a region. The region wherein we are most likely to encounter a hammer, for example, is a workshop. Here hammers are stored alongside other tools, such as saws and vices, and are used upon materials such as nails and wood. Each gains their standing from their relationship to one another within the region. Their standing together constitutes an equipmental totality.

The wider point that Heidegger seeks to make here is that not only do we encounter much of the world as ready-to-hand in the form of equipment (i.e. as things that are available for our use in some way), but also that we ourselves are drawn into very basic relationships on the basis of the way in which we come to use and rely on whole networks of equipment. To step into the workshop is to take up a place within the equipmental totality. It is to realise a form of being which apprehends the world by way of the possibilities revealed by one's relationship to the equipment therein. Understood in this way, equipment plays an absolutely pivotal role in our existence and our ways of understanding, which is not to say that technology determines what we are. We must, after all, have some reason for entering the workshop or any other region. T his reason is a part of our more general concerns, amongst which is the concern with our own being which defines the human as Dasein (see Stenner, 1998).

But even here there is a forewarning that human concerns may themselves be caught up within the "holding power" of immediacy:

In Dasein there lies an essential tendency towards closeness. All the ways in which we speed things up, as we are more or less compelled to do today, push us on towards the conquest of remoteness (Heidegger, 1962, p. 140).

In reaching towards what appears to be most close - the ever availability of equipment - we become compelled to think of equipment as a means to defeat distance and bring the world ever nearer, at ever greater speeds. Equipment is revealed as the means by which the world can be commanded to stand all-ready before us (that is, close to us in both the spatial and the temporal sense, see Cooper, 1993). Here it is worth recalling that the equipment Heidegger is concerned with at the time of writing is the then "new" technologies such as radio and hydroelectrification. In his writings after Being and Time the need to produce a very different account of how things stand for us under the shadow of these massive forms of equipment leads Heidegger to begin questioning concerning technology per se.

A lthough the account of modern technology which Heidegger produces in his essays "T he question concerning technology" (Heidegger, 1977a) and "T he age of the world picture" (Heidegger, 1977b) could not be more stark, what is 
questioned is the essence of the technological, rather than any given technology. This approach is worked out in the terms set by Heidegger's statements on truth. A s we noted earlier, these hold that truth, as correctness, can only fully arise from the comportment adopted towards the openness of beings in their unconcealment. What is unconcealed by comportment, properly speaking, is beings as they are in themselves: beings in their essence. To be open to the essence of some being is then to place oneself within the truth of the matter. Thus, to discern the "truth" of modern technology requires a full explication (an unconcealing) of the essence of the technological. It is the beginning of the thinking of this essence which Heidegger offers up as the "saving power" to the ravages of technical-rational world ordering in one of his most opaque writings, "Die Kehre" ("T he turning") (Heidegger, 1977c).

But "essence" must itself be thought of in a somewhat unusual fashion. Essence usually refers to that fundamental set of properties which defines some being as what it is. Heidegger regards this as defining an "inessential essence". What contrasting is "essential" is precisely that in any given being which expresses its "true" being:

What does the essential essence of something consist in? Presumably it lies in what the entity is in truth. The true essence of a thing is determined by way of the truth of the given being. But we are now seeking not the truth of essence but the essence of truth ... We think this essence in recollecting the Greek word alètheia, the unconcealment of beings (Heidegger, 1993b, p. 176).

Essential essence is given in unconcealment. It is the "truth" which comportment aligns with in "letting beings be". This allows Heidegger to attempt the bold formulation that the "truth of essence" is of a piece with the "essence of truth". Elsewhere though, notably in "T he question concerning technology", Heidegger speaks of essence - Wesen - in another sense. This is rendered in translation as "the way in which something pursues its course, the way in which it remains through time as what it is" (Heidegger, 1977a, p. 3). We might say that it equates to how something "proceeds forth", "takes place", or, as Weber (1996) has it, "goes on". Understood in this fashion, the essence of some being is an event, something which comes to pass and in so doing stakes out its place in the world.

Heidegger's questioning of the essence of technology fixes on two distinct ways in which it has come to pass or staked its place in Western history. The first of these Heidegger discerns by way of the Greek etymology of technology as technikon, which describes that which belongs to techné. Techné is a mode of revealing beings. It occurs in relation to unconcealment, and hence truth. Techné is a craft skill, but also a form of fine art and moreover an "art of the mind". It allows that something be brought forth that would not otherwise bring itself forth. In Heidegger's famous example, techné is akin to the construction of a bridge across the Rhine. Something is brought forth, but in so doing the river itself remains unchallenged.

Modern technology, by contrast, comes to pass in a "challenging" or a "setting-on" of the earth. Heidegger likens this to a hydroelectric plant built 

1977a, p. 16). The river is thereby "unlocked" or "exposed" as a thing to be "commanded" and "set-in-order" as a simple resource. The Rhine then comes to reveal itself, to take up its standing for us, in a manner entirely in accord with the demands of the hydroelectric industry. For Heidegger, what "comes to pass" through this exposure is pervasive:

What kind of unconcealment is it, then, that is peculiar to that which comes to stand forth through this setting-upon that challenges? Everywhere everything is ordered to stand by, to be immediately at hand, indeed to stand there just so that it may be on call for a further ordering. Whatever is ordered about in this way has its own standing. We call it standingreserve (Heidegger, 1977a, p. 17).

When beings are revealed as "standing-reserve", that is as resources which stand perpetually available for calculation and command, then technology stakes out its place as "Gestell" or "enframing". Enframing is a way of revealing that gathers together and orders what is revealed into a prearranged space of calculation. Beings that are "challenged forth" into unconcealment in this manner can only come to stand as objects entirely at the disposal of the human. The obvious danger here is that once under way, enframing is destined to also "set-on" and reveal humans themselves as forms of standing-reserve:

A s soon as what is unconcealed no longer concerns man [sic] even as an object, but does so, rather, exclusively as standing-reserve, and man in the midst of objectlessness is nothing but the orderer of the standing-reserve, then he comes to the very brink of a precipitous fall; that is, he come to the point where he himself will have to be taken as standing-reserve (Heidegger, 1977a, p. 27).

W hat is staked out here could, in one sense, not be more distinct from the relationship to the world that humans achieve by way of the equipmental totalities described in Being and T ime Yet as Dreyfus (1992) notes, the "Gestell" which so concerns the later Heidegger is effectively the expansion of the notion of region to a global scale. A $n$ equipmental totalisation. Thus does the former work project the grounds for later texts. A nd if we understand informing by way of the earlier remarks on the availability of the ready-at-hand, then it seems we are impelled to conclude that as a development in the technologies of informing, information technology must itself be in essence a form of enframing.

\section{V}

Such a conclusion would be a meagre and scarcely innovative result for our efforts at reading Heidegger alongside information technology. So let us make one last sortie, by enlisting the help of Samuel Weber's (1996) virtuoso reading of Die Frage nach der Teknik. Weber notes that "Ge-stell" (i.e. enframing) is a derivation from "stellen", meaning "to set" or "to place". This word has a wide usage in German, ranging from "to put in place" and "to order" through "to arrange" and "to supply". The usage Weber chooses to emphasise is the domestic. This includes possible descriptions such as "placing in drawers" or 
"arranging rooms". In this manner, Weber picks out a possible link between enframing and the more homely images of equipment placed in the workshop from Being and T ime. W hat it also suggests is that Ge-stell is in some sense the exponential proliferation of the kind of mundane ordering proper to the domestic sphere (we are reminded here of the links between oikos - the household - and economy, and of Margaret Thatcher's claim to be managing monetary affairs as the "housewife" of the nation).

So it would seem to be with information technology. For is not the assumed goal of a great many developments such as Groupware and virtual meetings, simply the engineering of telepresence where previously ordinary human contact, that activity beyond all else which qualifies the "homely", would have been deemed most desirable? A nd of course the rise of teleworking is also indicative of a peculiar mutation in the practices of the home. Weber, though, goes beyond this focus on the domestic to argue that Ge-stell would be more fluently rendered as "emplacement". This adequately captures the sense of "putting into place", but also carries some of the other resonances with "ordering" and "supplying". E mplacement is, for Weber, as much about the "placing on order" as it is the "ordering into place". It denotes the "summoning forth" or commanding aspect of what technology achieves, as well as the "staking out of place", the way in which technology dramatically re-shapes the environments in which we dw ell. E mplacement: commanding and world making. A good enough approximation of information systems design (see Lightfoot and Lilley, forthcoming; Wilson, 1997).

Weber also considers a further key Heideggarian term, herausfordern (to challenge, to call forth). In the standard translation of Die Frage ... it is noted that a literal English rendering of the term would be "to demand out hither". Herausfordern (challenging-forth) is structurally related to her vorbringen (to bring forth hither). Weber suggests that this latter term might be understood as "harbouring forth", thereby indicating a movement from the relative security of the harbour into the insecurity and risk of what lies beyond. Read in this way "harbouring forth", as that activity of unconcealing that is "set on" by the "challenging" of enframing, is laden with a sense of dread. Keeping this insecurity or dread uppermost then allows us to better grasp what is at stake in emplacement/enframing. B eings are "placed on order" as manipulate "standingreserve" and then "ordered into place" - literally emplaced. But these emplacements are themselves ordered in the face of great insecurity, since in summoning forth beings from the security of concealment, emplacing can only find standards to guide its activity within that same activity; which is to say that the desire for gathering ever closer and placing more firmly in and on order ensures that the resulting emplacements come to seem ever more provisional and insecure, much like outmoded defences. When humans themselves become rendered as standing-reserve then any possibility for finding a standard on which secure ordering can be based is seemingly lost.

In many ways Weber's translation also fails to escape the dreadful orbit of Ge-stell. But he does at least suggest to us some way out by underscoring the 

go on by way of their taking of place. Indeed, in an earlier questioning of the work of art as something midway between a "thing" and "equipment", Heidegger (1993b) similarly concludes that what is at work in art involves both a "fixing" and a "taking place". W hat is fixed is a figure, but what this figure in turn begins to open up is a "world". World here means a space wherein beings come into unconcealment. The work of art allows beings to take up standing before us, but can only achieve this by providing the security of a shelter, something set-up and fixed in place in advance of their coming to unconcealment. Inasmuch as beings are then able to "be themselves", truth is what then takes place:

In the work of art the truth of beings has set itself to work. "To set" here means "to bring to stand" ... The essence of the work of art would then be this: the truth of beings setting itself to work (Heidegger, 1993b, p. 162).

All this occurs under the sign of techné. Now, no matter how monstrous Gestell may appear, it conserves within it traces of techné, the essence of pre-modern technology. We may then be able to discern within the "setting up" and "taking place" of information technology, considered now as "insistent emplacement", what belongs to each of these modes of revealing.

When information systems are conceived solely on the basis of their power to engineer immediacy and telepresence, that is to order into place all concerned as calculable elements, then we may indeed conclude that what is set-up belongs to emplacement. And we may predict that the destiny of such emplacement is to relentlessly pursue yet greater availability and speed, in the face of rampant insecurity. Similarly, when what is "taking place" in information systems is regarded as the facilitation of communication, and this between "subjects" who act as supposed guarantors of their own standing, so again may we observe that the possibility of any lasting basis for standards to guide ordering is effaced. This occurs because the separation of people, as subjects, from information technology creates the circumstance where "people" gain their standing simply as orderers of information, as standing reserve. The fatal illusion is woven that an increase in ordering alone will bring us closer to being.

But in turning now to techné, we see other ways of regarding information systems. We are confronted with fragile shelters wherein things may pass into unconcealment. As a set of relations which become embedded in a figure (a network, say, or a system) then what is thereby constituted is a world. A world which has within it the possibility that something unexpected and unplanned may come to pass if the proper comportment is struck and beings are "let-be", not regarded simply as standing reserve. Crudely put, planning must be directed towards creating the space where things happen without prior rigid objectives. Yet a world constituted in this way is also one which is filled with dread, since in letting beings be it foregoes the opportunity of challenging and commanding. It is placed in the precarious position, pushed right up against the 
mystery of concealment, of waiting for the unconcealed to bring themselves forth into unconcealment. Such a world gives time.

All of which may render the inhabitants of that world - our nameless manager amongst them - in a state of perpetual anxiety. Yet we would recognise in this anxiety not an aversive state to be worked upon by a solid programme of training and skills improvement, but instead a certain openness to the vastness of the world which is opened up by information technology. This anxiety marks proper comportment, not a groundless fear. A s such we should begin to think through and question this anxiety in its own right, as a form of openness, and as something to be explored rather than managed out of existence. Because it is only by way of this anxiety that we may be able to discern how exactly things stand with us when the shadow of emplacement extends so greatly.

Tempting as it is to disturb our manager one final time, we finish by recalling one of Jorge Luis Borges' (1970) most famous tales - T lön, U qbar, Orbis Tertius. In this short story, fragments of another previously unknown world pass into this one, in the form of historical documents and then, gradually, strange objects whose purpose is at first unclear. It comes to pass that so numerous is the passage of artefacts and knowledge from the hidden world, that the two worlds begin to blend seamlessly into one. So it has been with our world and the development of information technology. We have, from Heidegger and others, compelling "histories" of the world to come and are everywhere surrounded by artefacts whose eventual destiny is indeterminate. Perhaps our only way of making sense of what is coming to pass is to turn again to those objects, to see, in the face of our considerable anxiety, what kinds of relationships become possible with whatever takes its place in unconcealment: $T$ lön, U qbar, Orbis Tertius.

\section{References}

Billig, M. (1996), Arguing and Thinking: A Rhetorical A pproach to Social Psychology, 2nd ed., Cambridge University Press, Cambridge.

Borges, J.L. (1970), Labyrinths: Selected Stories and Other Writings, Penguin, Harmondsworth.

Brown, S.D. and Pujol, J. with Curt, B.C. (1998). "As one in a web: discourse, materiality and the place of ethics", in Parker, I. (Ed.), Social Constructionism, Discourse and Realism, Sage, London.

Cooper, R. (1993), "Technologies of representation", in A honen, P. (Ed.), Tracing the Semiotic Boundaries of Politics, Mouten de Gruyter, Berlin.

Dreyfus, H. (1992), "Heidegger's history of the being of equipment", in Dreyfus, H.L. and Hall, H. (Eds), Heidegger: A Critical Reader, Blackwell, Oxford.

Haraway, D. (1991), Simians, Cyborgs and Women: The Reinvention of Nature, Free A ssociation Books, London.

Harvey, D. (1989), The Condition of Postmodernity, Blackwell, Oxford.

Heidegger, M. (1962), Being and T ime (translated by Macquarrie, J. and Robinson, E.), Blackwell, Oxford.

Heidegger, M. (1977a), "The question concerning technology" (translated by W. Lovitt), in T he Question Concerning Technology and Other Essays, Harper \& Row, New York, NY. 
Heidegger, M . (1977b), "T he age of the world picture" (translated by Lovitt, W.), in The Question Concerning Technology and Other Essays, Harper \& Row, New York, NY.

Heidegger, M. (1977c), "T he turning" (translated by Lovitt, W.), in The Question Concerning Technology and Other Essays, Harper \& Row, N ew York, NY.

Heidegger, M. (1993a), "On the essence of truth" (translated by Sallis, J.), in K rell, D.F. (E d.), Basic Readings: $M$ artin Heidegger, rev. ed., Routledge, London.

Heidegger, M. (1993b), "T he origin of the work of art" (translated by Hofstadter, A .), in Krell, D.F. (E d.), Basic Readings: M artin Heidegger, rev. ed., Routledge, London.

Kaleb, G. (1997), "Technology and philosophy", Social Research, Vol. 64 No. 3, pp. 1225-46.

Lightfoot, G.M. and Lilley, S. (forthcoming), Social Theory and Society, Oxford University Press, Oxford.

Steiner, G. (1992), H eidegger, rev. ed., Fontana, London.

Stenner, P. (1998), "Heidegger and questioning concerning psychology", Theory and Psychology, Vol. 8 No. 1, pp. 167-93.

Tsoukas, H. (1992), "Panoptic reason and the search for totality: a critical assessment of the critical systems perspective", Human Relations, Vol. 45 N o. 7, pp. 637-57.

Turkle, S. (1984), T he Second Self: Computers and the Human Spirit, Simon \& Schuster, New York, NY.

Weber, S. (1996), “Upsetting the set-up”, Mass M ediauras: Form, Technics, M edia, Stanford University Press, Stanford, CT.

W ilson, F.A . (1997), "T he truth is out there: the search for emancipatory principle in information systems design", Information Technology \& People, Vol. 10 No. 3, pp. 187-204.

Winograd, T. and Flores, F. (1986), Understanding Computers and Cognition, A blex, Norwood, CT.

Zimmerman, M.E. (1990), Heidegger's Confrontation with M odernity: Technology, Politics, Art, Indiana University Press, Bloomington, IN. 